\title{
Correspondence
}

\section{Restrictions on Soviet Scientists}

Sir,-The depressing story of the attempts by Dr Medvedev to accept an invitation to a conference in Sheffield (Nature, September 19) prompts me to raise the following issues. I have been to three conferences during the past month in various parts of Europe. At each conference papers by Soviet scientists were listed in the programme and abstracts were included; on each occasion none of the Russians turned up. One of these conferences was in Yugoslavia and on that occasion neither the Russian nor a Czech contributor was able to turn up, although both were due to give major addresses. At each of these conferences the organizers were caused embarrassment as well as regret by the inability of the speakers to come, and last-minute changes had to be made to the timetable in consequence. A further important consequence of these cancellations is that Western scientists are deprived of the benefit of meeting their Soviet opposite numbers.

At one of the conferences I attended, a letter was sent to the organizer by a Russian who was unable to come (such letters are not always sent, and sometimes the spcakers simply do not turn up without notice or explanation). In the letter the scientist concerned expressed his regret at his inability to come and added that he was looking forward to seeing his contribution printed in the official proceedings of the conference. The question then arose whether his contribution should in fact be printed, and it was agreed that this should not be done. It is, of course, hard on a Soviet scientist, who would have liked. to attend a conference but has been prevented by the failure of his authoritios to grant permission, not to see his work printed. On the other hand, as I pointed out, if the work is printed then the Soviet authorities receive, as it were, indirect kudos without even having put up the resources to enable the speaker to deliver his paper in person ; the Soviet authorities would have progressively less reason to permit their scientists to go abroad if their work is published as though they had been at the conference.

I submit therefore that it would be likely to be of long-term benefit to our Soviet colleagues and make it more probable that they would more often be allowed to come in future, if as a matter of principle conference organizers were to decline to print contributions from people who have not actually turned up in person at the conferences in question.

I should be interested to know the views of other readers concerning this suggostion.

Yours faithfully,

R. W. CAHN

University of Sussex,

Falmer, Brighton, Sussox

\section{Accelerating Somatic Cell Genetics}

Sin,--In your leading article on October 24 (Nature, 228, $318 ; 1970$ ), you attribute to Watkins and myself a discovery that we did not make. Watkins and I were the first to fuse together cells of human and murine origin, and we observed that in the fused cells DNA replication was markedly inhibited in the human nuclei. However, the discovery that human chromosomes are preferentially lost from proliferating man-mouse hybrid cells was not made by Watkins and myself, but by Mary C. Weiss and Howard Green (Proc. US Nat. Acad. Sci., 58, 1104; 1967). Yours faithfully, HENRY HARRIS

Sir William Dunn School of Pathology, University of Oxford.

\section{Population in Nigeria}

SIR,-I wish to make some comments on your leading article of September 12 relating to the discussion at the meeting of the British Association (Nature, 227, 1073; 1970). You are, of course, correct in your reporting, but there is a possible danger of misunderstanding from the comment which you attributed to me which states that I doubt whether Africa has a population problem. I would not like to leave an impression which would be wrong. What I did say was that we are sceptical of the great efforts being made on population control in Africa by some advanced countries. We are sceptical because our main problem is not that of high birth rate which would likely be followed by a great increase in population, but rather the problem of a high infant mortality rate.

To be more specific, may I explain in this way: the population of Nigeria is calculated at about 60 million. A large majority of these 60 million are young people of not more than 15 yoars of age and most of these young people will never live beyond the 8 ge of 15 -this is a medical fact. The result is that the effective population of Nigeria as regards her manpower is certainly not 60 million but may be between 20 and 30 million. It is obvious therefore that our concern should not be, as was suggested in the question directed to me, that we should control birth rate by limiting the number of ehildren in each family (which is the current practice in population control) but that of preventing the high infant mortality rate.

$$
\text { Yours faithfully, }
$$

\section{T. Adesanya Ige Grillo}

Department of Anatomy,

University of Ibadan, Nigeria.

\section{Evolution of Rifting in Africa}

SrR,-In his interesting comments (Nature, 227, 699; 1970) on our paper ${ }^{1}$, it seems that McConnell thinks we consider the phenomenon of sea floor spreading to bo taking place in the rift zone of East Africa. This is not so. The purpose of our communication was to bring together evidence from seismicity, age of faulting, age of voleanoes and interpretations of gravity anomalies and to suggest that they together indicate that rifting in East Africa is probably associated with attenuation of the lithospheric plate. This process, we envisage to precede spreading. The rift in East Africa cannot be a site of spreading for 